\title{
The Complementary Effect between Private Consumption and Government Spending: Effect on the Economy
}

\author{
Kida Nakije ${ }^{1 *}$ \\ ${ }^{1}$ Department of Banking and Finance, AAB College, Pristina, 10000, Kosovo
}

\begin{abstract}
This paper analyzes the relationship between final consumption and government spending, using the correlation and linear regression model. The objective of the research is whether government expenditures are complementary, substitute, or not related to private consumption to give positive effects on the economy. Methodology, quantitative secondary data were obtained from the World Bank, for five countries and processed with SPSS, 21 . The empirical analysis was verified through, Bivariate and Partial correlation and normality test. The Result, first, shows that government spending complements and replaces final consumption. Second, it is also confirmed that even when interacting with other variables, the complementary effect of final consumption is not eliminated despite the shocks coming from government spending. Third, by adding other variables to the model, the issue of complementarity and substitutability of the two main variables is not lost. As a result, findings, confirm that private consumption ( $\mathrm{InCt}$ ) and government spending (InGt), Gross Savings (GS), and per capita income (GDPpc), are in statistically significant and positive relationships with each other. The novelty of the paper is, government expenditures cause an increase in private consumption is to high value, showing the complementary effect of government expenditures on private consumption. Based on health expenditures, education, public order, internet provided by the state have increased the demand of families for these services, causing an increase in the share of services provided by the private sector.
\end{abstract}

JEL Classification: E21; H5; E2; R0.
Keywords:

Private Consumption;

Government Spending;

Gross Savings;

Western Balkans.

Article History:

Received: 23 February 2021

Revised: 25 May 2021

Accepted: 19 July 2021

Published: $01 \quad$ August 2021

\section{1- Introduction}

Government spending on overall economic activity is one of the most controversial issues in any economy. Authors in their studies have found evidence that government spending has cumulative effects (replacing each other) and is positively related in most cases [1,2]. Most households in the sample countries, in addition to disposable income from the public sector receiving from salaries (employees), also receive income from remittances (from their families abroad) increasing the general demand, while the private sector in the above growth has affected the growth of employment. The increase in employment has created additional costs by creating a moderate expansion of the economy of these countries. Over the years of analysis, it has often been found that although the demand for goods and services has increased the producers have often not approached them affecting the increase in prices but not in the double digits. However, with low per capita income in most countries, it is challenging to have a direct effect of final consumption on government spending. It is important to note that there is an income inequality among the population where some have above-average incomes, however, the economy has not benefited from the higher population income; they save or invest more compared to the population with that low income which spends income on consumption.

* CONTACT: nakije.kida@aab-edu.net

DOI: http://dx.doi.org/10.28991/esj-2021-01292

(C) 2021 by the authors. Licensee ESJ, Italy. This is an open access article under the terms and conditions of the Creative Commons Attribution (CC-BY) license (https://creativecommons.org/licenses/by/4.0/). 
Also, the population of these countries has debts in banks for home or medical expenses, school, etc. This characterizes them as consumers with not high expectations to spend, but the Covid crisis 2019 has accelerated purchases now to avoid high prices that may come later. This increased demand for goods and services in these countries has been accompanied by an increase in consumption in the first quarter and the third quarter of 2020. While due to the impossibility of movement of people there has been a drastic decline in demand and supply, significantly reducing the rates of economic growth in 2020 and the first quarter of 2021. The sample countries have stimulated public spending through recovery packages and have reduced taxes or deferred payments for a period of 6-9 months. However, the decrease in demand for these months of pandemics is another factor that has influenced businesses not to increase production even though taxes were reduced. Stimulating businesses from the government would be an incentive for businesses to recover and workers to receive wages, a positive indication that the government should go into debt to stimulate the economy. From this, it can be seen that consumer spending is as important as government spending; it is an indicator of the health of the economy.

According to the classical concept, the disposable income of households is equal to the amount of consumption and savings. Disposable income, when saved at a higher interest rate, is an encouraging incentive for households to incur expenses. Young Keynesians give an alternative explanation that households usually enter the credit market to mitigate their future expenses if they generate benefits from the loan money they have invested. Realistically rising interest rates now lead households to reduce current consumption and keep their money for future expenses. A change in interest rates, therefore, affects household behavior towards consumption. The following study found that changes in government spending respond positively to private consumption if there is no tax increase because it would reduce the income of households that would not have sufficient income for consumption [3]. "Government expenditure expansionary shocks are found to have a positive impact on output in the short term at the cost of higher inflation and public deficits and lower output in the medium and long term" [4].

Results are different, suggesting that private consumption increase over the recessionary time has effects if expansionary fiscal policies are used [5]. Even the study conducted in China for the years 1996-2013 which included 29 provinces was found to have a complementary effect between government spending on culture and education and private consumption. While the effect of substitution between government expenditures on construction, administrative management with private consumption has been found [6]. If the government increases spending, it directly affects the growth of employment through public investment. Employment growth increases aggregate demand for consumption but also for savings [7].

Even after a lot of research on the effect of the interaction between private consumption variables and government spending, it has not been concluded that these variables increase, decrease, complement, or replace each other because the effects of fiscal policies vary from country to country but also from one period of time to another. Also, the use of different models may give different results for the same variables. An impetus to analyze this issue is also the interacademic controversy on the one hand and the other hand what can the use of a simple model used in this study, Bivariate Correlation and Partial Correlation with variable parameters in time lag bring (in), to measure the relationship between government spending and private consumption, savings, per capita income and population in the Western Balkans.

\section{2- Literature Review}

Keynesian theory (1937), of absolute income, assumes that current household consumption corresponds to current disposable income that leads to increased production, employment, and so on. While the neoclassical theory assumes that household consumption will increase more from the expected income (in the long run) than from the current income. So, traditional macroeconomic models assume that government consumption functions through its impact on private consumption.

It has been investigated the extent to which government consumption replaces private consumption in nine East Asian countries and reveals that private consumption and government spending in Malaysia and Thailand are substitutes, in Indonesia and Singapore are complementary, close to zero are in the Philippines while moderate elasticity appears in China, Hong Kong, Japan, and Korea. [8] It has been proven that the complementary effect between private consumption and government spending has to do with an expansionary fiscal policy that is effective in stimulating aggregate demand. While the effects will be reversed if private consumption and government spending are substitutes, an increase in government spending will be compensated from private consumption decrease (aggregate demand is declining and may even be negative). One study analyzes how productive spending is to get a positive response from private consumption, and this is seen with pessimism by the fact that government spending increases private consumption only if the productivity of government spending is relatively high [9].

Hok (2020) [10] was used the Markov-Switching Autoregressive (MSAR) model to investigate the non-linear (nonKeynesian) impact of government spending on private consumption in Cambodia during the period 1987-2015. The result shows that in Cambodia there was a co-linear effect of investments on household consumption due to the current value of taxes during the period of political instability (1994-1998 and 2004-2006). This study showed that the two 
indicators tax increase and unsustainable policies are factors that prevented the efficiency of government spending on private consumption. Households distribute income partly for consumption and the rest for investment, the profit from the investment that the family receives meets their expenses. Conversely, if interest rates are high, borrowing households spend less. Rising inflation has effects on increasing the cost of living, forcing consumers to reduce consumption as long as inflation is rising.

The study uses annual time series data for 12 West African countries (ECOWAS) such as Benin, Burkina Faso, Cote d'Ivoire, Gambia, Ghana, Guinea-Bissau, Mali, Niger, Nigeria, Senegal, Sierra Leone, and Togo. The variables in the research are household final consumption expenditures, gross domestic product (GDP), and government final consumption expenditures [11]. The findings show that government consumption negatively affects private consumption therefore government consumption does not stimulate aggregate demand in ECOWAS countries.

Almosabbeh (2020) analyzed the relationship between government spending and private consumption and concluded that the effect of government spending on household spending was not significant in the long run, although the two variables were substitutable for the other with a coefficient of 0.8699 which is quite high. Relationships and aggregation are caused by positive shocks to government spending [12]. Dawood \& Francois (2018) conducted a panel analysis at the level of 24 African countries examining the relationship between private consumption and public consumption which showed that private and government consumption are Edgeworth's substitutes [13].

Another study analyzed the impact of government consumption on private consumption in Indonesia during the period 1990-2012 using the Almost Ideal Demand System (AIDS) model to analyze quarterly data on household consumption, investment, government spending, and imports. The results confirm that government spending complements household consumption. As the economy grows, the government's economic policies should tend to focus more on economic stabilization [14]. The literature mentioned above shows the importance of complementarity/substitutability between government spending and private consumption. Therefore, Kosovo, Albania, Northern Macedonia, Bosnia Herzegovina, and Serbia should promote general private consumption for a positive effect on the economy. Therefore, Kosovo, Albania, Northern Macedonia, Bosnia and Herzegovina, and Serbia must promote overall private consumption for a positive effect on the economy.

\section{3- Research Methodology}

A Flowchart research methodology has been developed to explain the process of conducting a scientific paper.

\begin{tabular}{|c|c|}
\hline \multirow{6}{*}{$\begin{array}{l}\text { Flowchart research } \\
\text { methodology }\end{array}$} & $\begin{array}{l}\text { Step 1: Problem Research-Can aggregate demand in the country increase if government spending and } \\
\text { private consumption mechanisms are used? }\end{array}$ \\
\hline & $\begin{array}{l}\text { Step 2: Hipothesies } \mathbf{H}_{1} \text { : The complementary effect between private consumption and government spending } \\
\text { has a positive effect on the economy. }\end{array}$ \\
\hline & $\begin{array}{l}\mathbf{H}_{2}: \text { Relationship between Government Expenditures, Private Consumption, GDP per capita, and the } \\
\text { population is not positive with all variables. }\end{array}$ \\
\hline & $\begin{array}{l}\text { Step 3: The objective of the research is whether government expenditures are complementary, substitute, } \\
\text { or not related to private consumption to give positive effects on the economy. }\end{array}$ \\
\hline & Step 4: Literature review- Classical and Neoclassical theory \\
\hline & Exploratory research technique \\
\hline \multirow{12}{*}{$\begin{array}{l}\text { Basic method selection } \\
\text { and data analysis }\end{array}$} & Secondary data: Government Expenditures, Private Consumption, GDP per capita, and the population \\
\hline & Selection of sample desing: Kosovo, Albania, Northern Macedonia, Bosnia Herzegovina and Serbia \\
\hline & Database: World Bank Report. https://databank.worldbank.org). \\
\hline & Colection of data: Data in millions of \$US calculated per capita \\
\hline & Data processing technique: Results are obtained by SPSS 21 \\
\hline & Econometric model: Ordinary Least Squares (OLS); Bivariate, and Partial correlation; Normality test \\
\hline & Data analysis: Correlation between the variables is long time $\mathrm{InCt}$ and $\mathrm{InGt}$ is quite strong and positive. \\
\hline & The two variables are complementary and substitute for each other and the positive effects on the economy. \\
\hline & The Savings contribution is positive. \\
\hline & Novelty:The novelty of the paper is that government expenditures cause an increase in private consumption \\
\hline & to high values, showing the complementary effect of government expenditures on private consumption. \\
\hline & Conclusion: A balanced increase in Government Spending is welcome, giving an effect on Private Consumption. \\
\hline
\end{tabular}

Scheme 1. Flowchart research methodology. 
The connection between the theoretical and empirical aspects in this study is made with the econometric model Ordinary Least Squares (OLS), Bivariate, and Partial correlation.Quantitative statistical data collected World Bank Report. [Retrieved 2021-03-12] Available at: https://databank.worldbank.org).

Galton (1885) [15] for the first time defined the term "regression" and completed the theory of bivariate correlation. Ordinary Least Squares (OLS) is a method of statistical analysis that evaluates the relationship between one or more independent variables and a dependent variable and was first introduced by the French mathematician Legendre [16]. Regression as a term, on the other hand, was introduced by Francis Galton (1822-1911) and later confirmed by Pearson, known for the law of universal regression of human length. Bravais, Gauss, Laplace, and Plana also studied distribution in the early 19th century [17]. Galton noted that (r) measures the proximity of "correlation" and suggested that (r) could not be greater than 1 (although he had not yet recognized the idea of negative correlation [18]. Seven years later, GaltonPearson developed the mathematical formula for measuring the moment correlation of the Pearson product. Our focus is on the correlation coefficient as a calculation index used to measure bivariate and partial correlation. The following formula represents the Pearson correlation:

$$
\operatorname{cov}(x, y) \text { or } r=\frac{\sum(X i-\bar{Y})(Y i-\overline{Y i})}{\left[\sum(X i-\overline{\mathrm{X}})^{2} \sum(Y i-\overline{\mathrm{Y}})^{2}\right]^{1 / 2}}
$$

where; $\boldsymbol{r}_{x y}=$ Pearson $\mathrm{r}$ correlation coefficient between $\mathrm{x}$ and $\mathrm{y} ; \mathbf{n}=$ number of observations; $\mathbf{x}_{\mathbf{i}}=$ value of $\mathrm{x} ; \mathbf{y}_{\mathbf{i}}=$ value of y.

There were used basic statistical tests that meet five assumptions to interpret the data, validity, independence, linearity, or assumption of the direct relationship between each of the two variables. [19].We refrain from reviewing all the criteria in detail and focus on the assumption of normality [20] through the statistical test Shapiro-Wilk [21].

The following hypotheses will be tested:

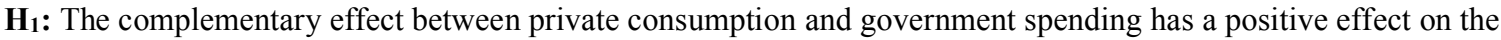
economy.

$\mathbf{H}_{2}$ : Relationship between Government Expenditures, Private Consumption, GDP per capita, and the population is not positive with all variables.

The invalid hypothesis $\left(\mathrm{H}_{0}\right)$ and the alternative hypothesis $\left(\mathrm{H}_{1}\right)$ of the correlation significance test are expressed below (two-tailed test):

$\mathbf{H}_{0}: \rho=0$ (the population correlation coefficient is 0 );

$\mathbf{H}_{1}: \rho \neq 0$ (the population correlation coefficient is not 0 );

where; $\rho$ is the population correlation coefficient.

Analysis of bivariate correlation [22] measures the values in the range $(-1,+1)$. The statistical test of the correlation coefficient of the sample between the two variables $\mathrm{x}$ and $\mathrm{y}$ is indicated by $\mathrm{r}$ or $\mathrm{r}_{\mathrm{xy}}$, and is calculated [23].

$$
r_{x y}=\frac{\operatorname{cov}(\mathrm{x}, \mathrm{y})}{\sqrt{\operatorname{var}(\mathrm{x})} x \sqrt{\operatorname{var}(\mathrm{y})}}
$$

where; $\operatorname{cov}(\mathbf{x}, \mathbf{y})$ is the covariance of the $\mathrm{x}$ and $\mathrm{y}$ sample; $\operatorname{var}(\mathbf{x})$ is the variance of the $\mathrm{x}$ sample; $\operatorname{var}(\mathbf{y})$ is the variance of the y sample.

Pearson's selection has produced test statistics for bivariate Pearson Correlation: The statistical significance test was checked through asterisks $(* *)$ located on the variables when they showed a statistically significant correlation at the level of 0.01 (2-tailed).

The second hypothesis, Partial Correlation has been used because the data group is characterized by more than two variables. Partial correlation is a measure, as the correlation between two variables, e.g., private consumption and government spending, and is influenced by a third variable for example GDPpc, Gross savings (GS), or population. In this case, if we find a significant relationship between the three variables and suspect that the correlation between private consumption and government spending is the result of their individual relations to GDPpc (ie C-GDPpc and GS-GDPpc), we remove the assumed linear relationships between C-GDPpc, and between GS-GDPpc. The correlation between Private Consumption- Gross Savings (C-GS) is recalculated, which is now a Partial correlation after the GDPpc effect is removed. Partial correlation is being used extensively, especially in genetics [23].

For example, $\mathrm{p}(\mathrm{X}, \mathrm{Y}: \mathrm{Z})$, is a first-order partial correlation coefficient, because it is conditioned solely on the (Z) variable $[24,25]$. Consider three random variables $X, Y$, and $Z$. The partial correlation coefficient, $p(X, Y: Z)$, can be expressed in terms of Pearson correlation coefficients $p(X, Y), p(X, Z)$, and $p(Y, Z)[26]$. 
$p(X, Y: Z)=\frac{\mathrm{p}(\mathrm{X}, \mathrm{Y})-\mathrm{p}(\mathrm{X}, \mathrm{Z})-\mathrm{p}(\mathrm{Y}, \mathrm{Z})}{\sqrt{\left[1-\mathrm{p}^{2}(\mathrm{X}, \mathrm{Z})\right]\left[1-\mathrm{p}^{2}(Y, Z)\right]}}$

A lower value of $p(X, Y: Z)$ shows that the variable $Z$ strongly influences the relationship between $Z$ and $Z$, for example, $p(X, Y) \sim p(X, Z) p(X, Z)$. But $p(X, Y: Z)$ may be low because the Pearson correlation coefficients $p(X, Y)$, $p(X, Z)$, and $p(X, Z)$ are small. That, in our case, concentrating on the relation [25]. We assume:

$d(X, Y: Z) \equiv p(X, Y)-p(X, Y)-p(Y, Y: Z)$

So, it is assumed as the correlation effect of the element $\mathrm{Z}$, on the elements $\mathrm{X}$ and $\mathrm{Y}$.

The methodology used in the Shapiro-Wilk, [21], (SW) test for normality is as follows. The data is adjusted so that $x_{I} \leq \ldots \leq x_{n}$. and Sum Squares(SS) is calculated as follows:

$$
S S=\sum_{i=1}^{n}(\overline{X i}-\overline{Y i})^{2}
$$

To make the results of the study even more convincing for the complementarity of the two main study variables (Cit, Git) without including the other variables, we use Linear Regression through the ordinary Least Squares (OLS) method [16].

The Regression Equation is used to estimate the dependent variable (Y) based on the independent variable (X). In this case the simple regression model. The model linear regression for $(n)$ observation can be written as (https://www.stat.purdue.edu/ fmliang/STAT512/lect2.pdf):

$$
\gamma_{\mathrm{i}}=\beta_{0}+\beta_{1} \chi_{1}+\mathrm{ei}, \quad i=1,2, \ldots, n
$$

where; $\gamma_{i}$, dependent variables; $\beta_{0}$, constant; $x_{1}$, explanatory variables; $e_{i}$, standard errorE (ei) $=0$ for $i=1,2, \ldots, n$, or equivalently $E\left(y_{i}\right)=\beta_{0}+\beta_{1} \chi_{1}$. Ordinary Least Squares (OLS) is to estimate $\beta_{0}$ and $\beta_{1}$.

\section{4- Data Analysis}

\section{4-1- Descriptive Statistic}

The following analysis presents, mean value, standard deviation, minimum and maximum. The data are in mil. Dollars, (\$ 000000$)$, each data is converted into per capita. In descriptive statistics is found that the value of the Gross Savings variable around the average is more concentrated because the value distribution is 208 units from the average of 1280 units, this distribution is lower. And has a minimum value of GDPpc (Yt) the value distribution is 573 units out of the average 6415. The second best variable in terms of distribution is Private Consumption ( $\mathrm{InCt}$ ) which has an average of 4374 units with an average distribution of 372.9 units. For variables, government spending, and population, the average distribution normality test is performed.

Table 1. Descriptive statistics.

\begin{tabular}{cccccc}
\hline Variables & Obs & Mean & Std. Dev. & Min & Max \\
\hline Gross savings- InGS & 15 & 1280.18 & 208.26 & 886.55 & 1733.72 \\
Y_t & 15 & 6415.24 & 573.63 & 5295.57 & 7482.82 \\
InGt & 15 & 34679.21 & 3517.89 & 27573.15 & 39570.39 \\
InCt & 15 & 4374.77 & 372.99 & 3598.62 & 5012.91 \\
InPt & 15 & 36528.33 & 44276.8 & 35732.24 & 37112.73 \\
\hline
\end{tabular}

Note: Results are obtained by SPSS 21; all tables and figures in the study were compiled by the author.

An overview of the economic performance of the sample countries.

- Indicators of variables analyzed for Albania have this performance:

The economic growth rates in Albania are projected to decrease to 2.2\% in 2020 which has occurred [27] The COVID19 pandemic plunged the country into a public health crisis. Statistics for Albania (table 2), presents Gross Savings around the most concentrated average because the value distribution is 73,316 units from the average of 783.93 units, this distribution is lower. The other variables have a less concentrated value distribution than the mean. This means that in Albania savers are growing while GDPpc has a positive growth trend along with private consumption as a very large contributor to GDP. 
Table 2. Descriptive statistics, study variables for Albania.

\begin{tabular}{|c|c|c|c|c|c|c|c|c|c|c|}
\hline \multirow{2}{*}{ Albania } & \multirow{2}{*}{$\begin{array}{l}\text { N } \\
\text { St. }\end{array}$} & \multirow{2}{*}{$\frac{\text { Minimum }}{\text { Statis. }}$} & \multirow{2}{*}{$\begin{array}{c}\text { Maximum } \\
\text { Statis. }\end{array}$} & \multirow{2}{*}{$\begin{array}{l}\text { Mean } \\
\text { Statis. }\end{array}$} & \multirow{2}{*}{$\frac{\text { Std. Dev. }}{\text { Statis. }}$} & \multirow{2}{*}{$\begin{array}{c}\text { Variance } \\
\text { Statis. }\end{array}$} & \multicolumn{2}{|c|}{ Skewness } & \multicolumn{2}{|c|}{ Kurtosis } \\
\hline & & & & & & & Statis. & Std. Erro. & Statis. & Std. Erro. \\
\hline Gross savings-InGS & 1 & 666.69 & 911.37 & 783.93 & 73.31 & $5,375.21$ & 0.041 & 0.580 & -1.115 & 1.121 \\
\hline GDP per capita & 1 & $2,887.37$ & $5,075.35$ & $4,058.42$ & 653.95 & $427,661.38$ & -0.384 & 0.580 & -0.705 & 1.121 \\
\hline GovernmentSpending & 1 & $29,639.96$ & $56,562.628$ & $44,855.01$ & $9,189.28$ & $84,442,942.98$ & -0.378 & 0.580 & -1.176 & 1.121 \\
\hline Private Consumtion & 1 & $1,888.46$ & $3,736.79$ & $3,050.09$ & 588.75 & $346,627.77$ & -0.954 & 0.580 & -0.605 & 1.121 \\
\hline Population, total & 1 & $2,866.376$ & $3,026,939$ & $2,925.018$ & $52,600.64$ & $2,766,827,897.02$ & 0.835 & 0.580 & -0.605 & 1.121 \\
\hline
\end{tabular}

- Indicators of variables analyzed for Kosovo have this performance:

In the descriptive statistics for Kosovo (Table 3), it is found that the value of the Government spending (Gt) variable around the average is more concentrated because the value distribution is 70.51 units from the average of 372.02 units, this distribution is lower. The other variables have a distribution of values approximately equally concentrated by the mean. Kosovo has a positive performance of government spending which stimulates the growth of private consumption by contributing to the economic growth of the country. As savings increase, contributors are the diaspora. With a positive but low GDP growth, it does not favour civic welfare much.

Table 3. Descriptive statistics, study variables for Kosovo.

\begin{tabular}{|c|c|c|c|c|c|c|c|c|c|c|}
\hline \multirow{2}{*}{ Kosovo } & \multirow{2}{*}{$\begin{array}{l}\text { N } \\
\text { St. }\end{array}$} & \multirow{2}{*}{$\begin{array}{c}\text { Minimum } \\
\text { Statis. }\end{array}$} & \multirow{2}{*}{$\begin{array}{c}\text { Maximum } \\
\text { Statis. }\end{array}$} & \multirow{2}{*}{$\begin{array}{l}\text { Mean } \\
\text { Statis. }\end{array}$} & \multirow{2}{*}{$\begin{array}{c}\text { Std. Dev. } \\
\text { Statis. }\end{array}$} & \multirow{2}{*}{$\begin{array}{c}\text { Variance } \\
\text { Statis. }\end{array}$} & \multicolumn{2}{|c|}{ Skewness } & \multicolumn{2}{|c|}{ Kurtosis } \\
\hline & & & & & & & Statis. & Std. Erro. & Statis. & Std. Erro \\
\hline Gross savings -InGS & 1 & 432.556 & $1,010.521$ & 698.86 & 187.04 & $34,985.631$ & -0.035 & 0.580 & -0.945 & 1.121 \\
\hline GDP per capita & 1 & $2,625.47$ & $4,193.631$ & $3,401.82$ & 467.99 & $219,015.971$ & 0.072 & 0.580 & -0.824 & 1.121 \\
\hline GovernmentSpending & 1 & 297.044 & 480.992 & 372.02 & 70.51 & $4,972.821$ & 0.842 & 0.580 & -0.956 & 1.121 \\
\hline Private Consumption & 1 & $2,352.436$ & $3,731.694$ & $2,968.79$ & 483.57 & $233,848.642$ & 0.346 & 0.580 & -1.151 & 1.121 \\
\hline
\end{tabular}

- Indicators of variables analyzed for Bosnia Herzegovina have this performance:

In Bosnia and Herzegovina (Table 4), it is found that the value of the Gross Savings variable around the average is more concentrated because the value distribution is 395.94 units from the average of 2,929.97 units, this distribution is lower. While there is a growing GDP, government spending does not contribute much to the growth of private consumption because it is seen that private consumption is less concentrated around the average.

Table 4. Descriptive statistics, study variables for Bosnia Herzegovina.

\begin{tabular}{|c|c|c|c|c|c|c|c|c|c|c|}
\hline \multirow{2}{*}{$\begin{array}{c}\text { Bosnia } \\
\text { Herzegovina }\end{array}$} & \multirow{2}{*}{$\begin{array}{l}\text { N } \\
\text { St. }\end{array}$} & \multirow{2}{*}{$\begin{array}{c}\text { Minimum } \\
\text { Statis. }\end{array}$} & \multirow{2}{*}{$\begin{array}{c}\text { Maximum } \\
\text { Statis. }\end{array}$} & \multirow{2}{*}{$\begin{array}{l}\text { Mean } \\
\text { Statis. }\end{array}$} & \multirow{2}{*}{$\frac{\text { Std. Dev. }}{\text { Statis. }}$} & \multirow{2}{*}{$\begin{array}{c}\text { Variance } \\
\text { Statis. }\end{array}$} & \multicolumn{2}{|c|}{ Skewness } & \multicolumn{2}{|c|}{ Kurtosis } \\
\hline & & & & & & & Statis. & Std. Erro. & Statis. & Std. Erro. \\
\hline Gross savings- InGS & 1 & $2,255.954$ & $3,745.125$ & $2,929.97$ & 395.94 & $156,769.324$ & 0.444 & 0.580 & 0.267 & 1.121 \\
\hline GDP per capita & 1 & $12,981.431$ & $15,870.281$ & $14,248.542$ & 794.70 & $631,562.080$ & 0.599 & 0.580 & -0.280 & 1.121 \\
\hline GovernmentSpending & 1 & $13,295.250$ & $17,345.831$ & $15,431.40$ & $1,032.99$ & $1,099,072.620$ & -0.491 & 0.580 & 0.837 & 1.121 \\
\hline Private Consumption & 1 & $11,290.200$ & $16,323.231$ & $16,891.40$ & $1,999.19$ & $1,067,072.810$ & -0.491 & 0.580 & 0.580 & 1.121 \\
\hline Population, total & 1 & $3,323.929$ & $3,764.194$ & $3,252.038$ & $72,407.413$ & $5,242,833,589.971$ & -1.251 & 0.580 & 0.516 & 1.121 \\
\hline
\end{tabular}

- Indicators of variables analyzed for North Macedonia have this performance:

In Northern Macedonia (Table 5), it was found that the value of the private consumption variable around the average is more concentrated because the value distribution is 292.21 units from the average of 3,345.47 units, this distribution is lower. While it stands worse with Gross Saving and Government Expenditures not contributing enough as part of GDP. While GDP per capita is positive but has a relatively low growth.

Table 5. Descriptive statistics, study variables for North Macedonia.

\begin{tabular}{|c|c|c|c|c|c|c|c|c|c|c|}
\hline \multirow{2}{*}{ North Macedonia } & \multirow{2}{*}{$\begin{array}{l}\text { N } \\
\text { St. }\end{array}$} & \multirow{2}{*}{$\begin{array}{c}\text { Minimum } \\
\text { Statis. }\end{array}$} & \multirow{2}{*}{$\begin{array}{c}\text { Maximum } \\
\text { Statis. }\end{array}$} & \multirow{2}{*}{$\begin{array}{l}\text { Mean } \\
\text { Statis. }\end{array}$} & \multirow{2}{*}{$\begin{array}{c}\text { Std. Dev. } \\
\text { Statis. }\end{array}$} & \multirow{2}{*}{$\begin{array}{c}\text { Variance } \\
\text { Statis. }\end{array}$} & \multicolumn{2}{|c|}{ Skewness } & \multicolumn{2}{|c|}{ Kurtosis } \\
\hline & & & & & & & Statis. & Std. Erro. & Statis. & Std. Erro. \\
\hline Gross savings- InGS & 1 & 402.58 & $2,002.513$ & $1,165.70$ & 470.67 & $221,533.66$ & 0.049 & 0.580 & -0.947 & 1.121 \\
\hline GDP per capita & 1 & $3,591.26$ & $5,394.28$ & $4,585.44$ & 552.07 & $304,783.70$ & -0.288 & 0.580 & -0.743 & 1.121 \\
\hline GovernmentSpending & 1 & $23,995.06$ & $31,080.23$ & $28,158.72$ & $2,171.77$ & $4,716,610.20$ & -0.871 & 0.580 & -0.197 & 1.121 \\
\hline Private Consumption & 1 & $2,746.46$ & $3,822.57$ & $3,345.47$ & 292.21 & $85,390.88$ & -0.329 & 0.580 & 0.034 & 1.121 \\
\hline Population, total & 1 & $2,057,048$ & $2,082,958$ & $2,071,907$ & $8,109.263$ & $65,760,161.571$ & -0.334 & 0.580 & -0.943 & 1.121 \\
\hline
\end{tabular}


- Indicators of variables analyzed for Serbia have this performance:

In Serbia (Table 6), it is found that the value of the Gross Savings variable around the average is more concentrated because the value distribution is 178.40 units from the average of 822.44 units, this distribution is lower. The distribution of the value of Private Consumption and Government Expenditure, around the average, is less concentrated therefore the normality test for such variables is performed. In Serbia, there is a positive trend of GDP growth while private consumption and government spending have had a moderate increase in recent years but act as a stimulus to economic movements.

Table 6. Descriptive statistics, study variables for Serbia.

\begin{tabular}{|c|c|c|c|c|c|c|c|c|c|c|}
\hline \multirow{2}{*}{ Serbia } & \multirow{2}{*}{$\begin{array}{l}\text { N } \\
\text { St. }\end{array}$} & \multirow{2}{*}{$\begin{array}{c}\text { Minimum } \\
\text { Statis. }\end{array}$} & \multirow{2}{*}{$\frac{\text { Maximum }}{\text { Statis. }}$} & \multirow{2}{*}{$\begin{array}{l}\text { Mean } \\
\text { Statis. }\end{array}$} & \multirow{2}{*}{$\frac{\text { Std. Dev. }}{\text { Statis. }}$} & \multirow{2}{*}{$\begin{array}{c}\text { Variance } \\
\text { Statis. }\end{array}$} & \multicolumn{2}{|c|}{ Skewness } & \multicolumn{2}{|c|}{ Kurtosis } \\
\hline & & & & & & & Statis. & Std. Erro. & Statis. & Std. Erro. \\
\hline Gross savings- InGS & 1 & 643.15 & $1,277.38$ & 822.44 & 178.40 & $31,827.02$ & 1.052 & 0.580 & 1.525 & 1.121 \\
\hline GDP per capita & 1 & $4,392.27$ & $6,880.53$ & $5,781.98$ & 668.79 & $447,287.95$ & -0.643 & 0.580 & 0.389 & 1.121 \\
\hline GovernmentSpending & 1 & $70,454.48$ & $93,603.60$ & $84,578.89$ & $6,094.65$ & $37,144,760.03$ & -1.389 & 0.580 & 2.002 & 1.121 \\
\hline Private Consumption & 1 & $3,253.51$ & $4,700.57$ & $4,220.95$ & 390.97 & $152,863.93$ & -1.635 & 0.580 & 2.271 & 1.121 \\
\hline Population, total & 1 & $6,982.084$ & $7,463.157$ & $7,236 ., 271$ & 157,799 & $24,900,534,416.95$ & -0.116 & 0.580 & -1.306 & 1.121 \\
\hline
\end{tabular}

- Economic situation and COVID-2019 in the countries part of the study

The fiscal deficits of the countries of the World Bank Group (2020) [27]. Western Balkans region in 2020 will widen significantly as a result of large expenditures on health, in support of businesses, and the unemployed. Kosovo has a good position, public debt is $17.2 \%$; Albania records higher values of public debt with $67.5 \%$ of GDP; North Macedonia has a public debt of $48.8 \%$; Bosnia and Herzegovina has $31.7 \%$ of GDP; Serbia also has a high debt of $52 \%$. While, Budget Balance, percentage of GDP is better $\mathrm{BiH}$ with $1 \%$, Kosovo with $0.7 \%$ and Serbia with $0.7 \%$. Whereas, real GDP growth in Albania is expected to be $-8.4 \%$ in 2020; $\mathrm{BiH}$ me $-3.2 \%$; Kosovo $-8.8 \%$; North Macedonia me - 4.1 \%; Serbia -3.0 \%; (Schiffbauer, M. T., \& World Bank. (2020)[28].

The causes of this contraction are the control measures taken by the governments of these countries and the reduction of the demand for goods and services. While we see that, private consumer spending in the EU fell by $4.1 \%$ in Q1 2020 . The EU-27 countries also had a significant decline in consumer spending (-12\%) in the second quarter of 2020 . The Spain (-20.0\%), Ireland (-19.1\%), Malta (-19.0\%) and Latvia (-18.3\%), Germany $11.1 \%$, Bulgaria with -2.1 had the largest declines. There was a $20 \%$ increase in the third quarter in Luxembourg, Ireland, Malta, Slovenia, and Spain, while in Germany the increase was $10.8 \%$ [29].

\section{4-1-1- Descriptive Statistics for Each Variable by Year}

The trend of savings is up and down but not with big differences until 2017. The year 2018 has an increasing trend of gross savings for all countries in the sample.

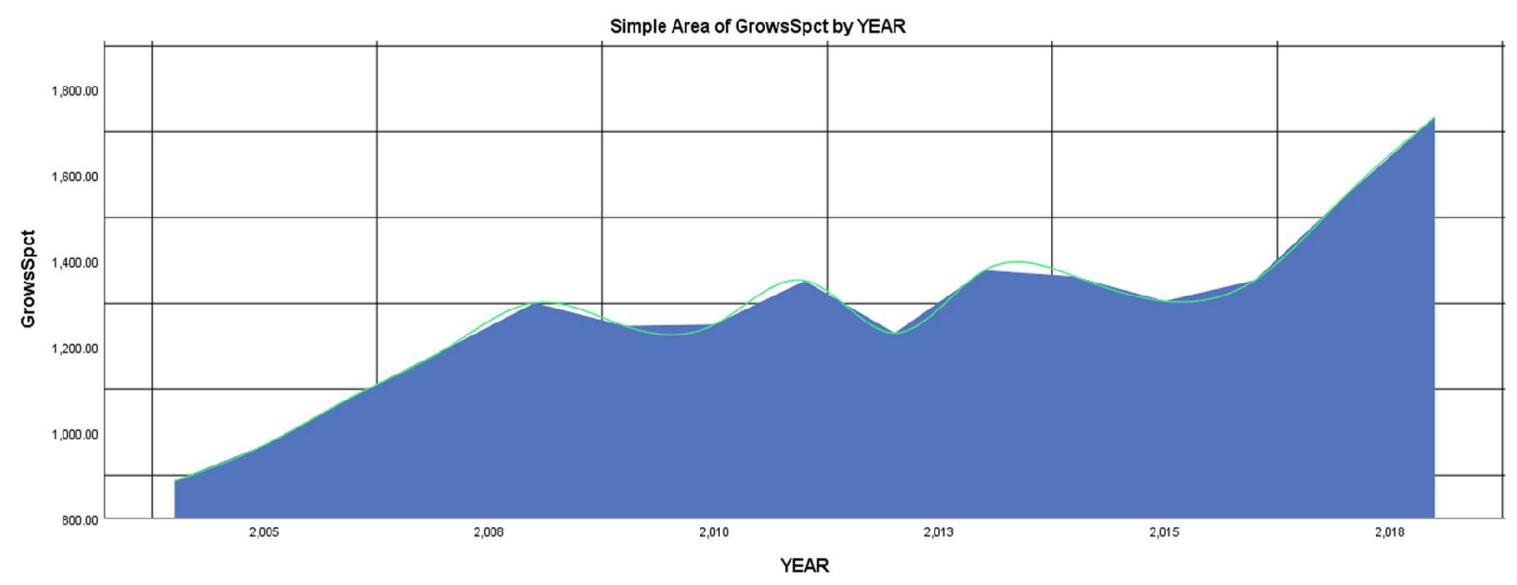

Figure 1. The Gross Savings Performance in the years 2004-2018.

The trend of GDP per capita growth for all countries is low in 2004 but with a continuous increase during the years 2005-2009. A slow growth trend has continued in the years 2010 to 2015, improving in the following years. 


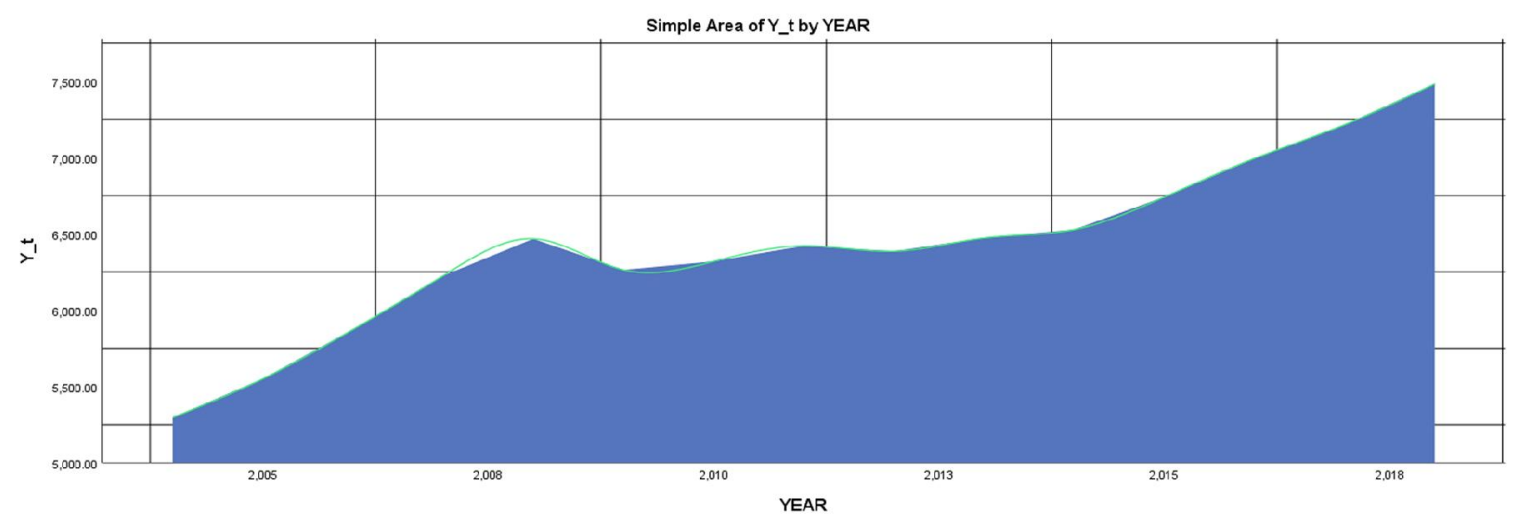

Figure 2. The GDPpc Performance in the years 2004-2018.

All countries in the sample have an increase in Government Spending (Gt) from 2004 to mid-2013. While there is a significant decline in this spending in the second quarter of 2013 deepening in 2014. The year 2015 is considered the best regarding the possibility of increasing government spending by continuing with the same trend for the next 3 years. An increase of emphasis on $\mathrm{Gt}$ is in 2018 which is considered positive for the economies of the sample countries.

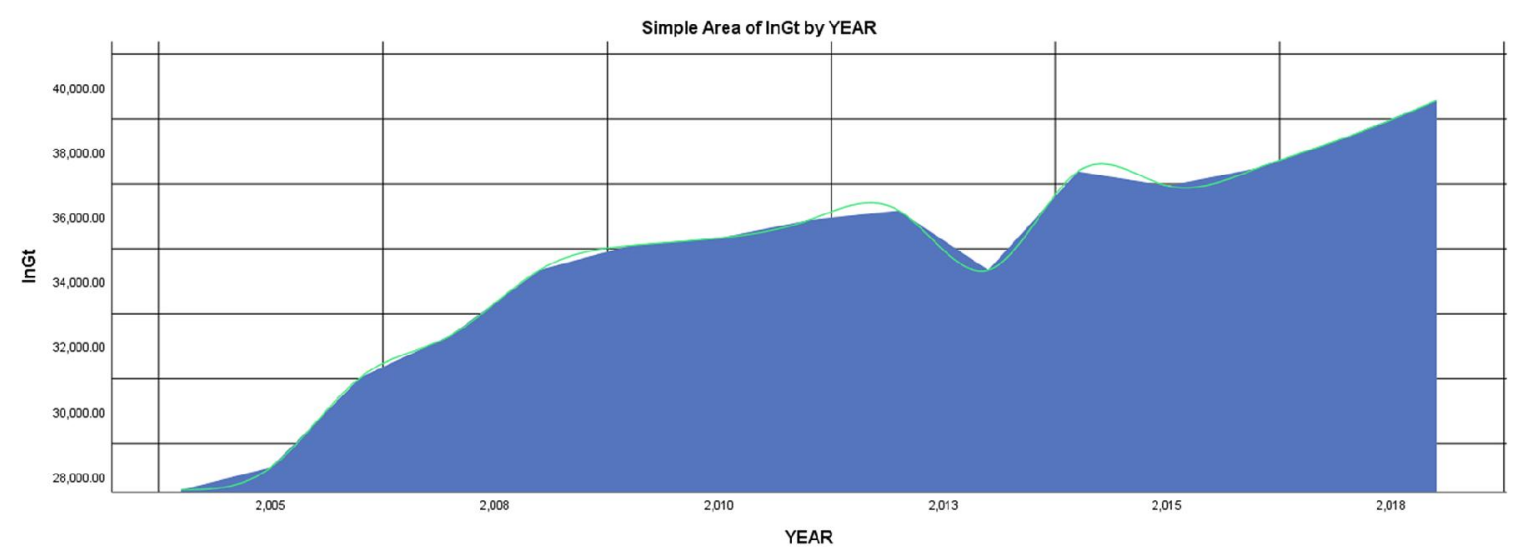

Figure 3. The Gt Performance in the years 2004-2018.

The figure shows an increase in final household consumption from 2004 to 2008. The decline is visible from 2009 to 2016, while a significant increase continues in the following years.

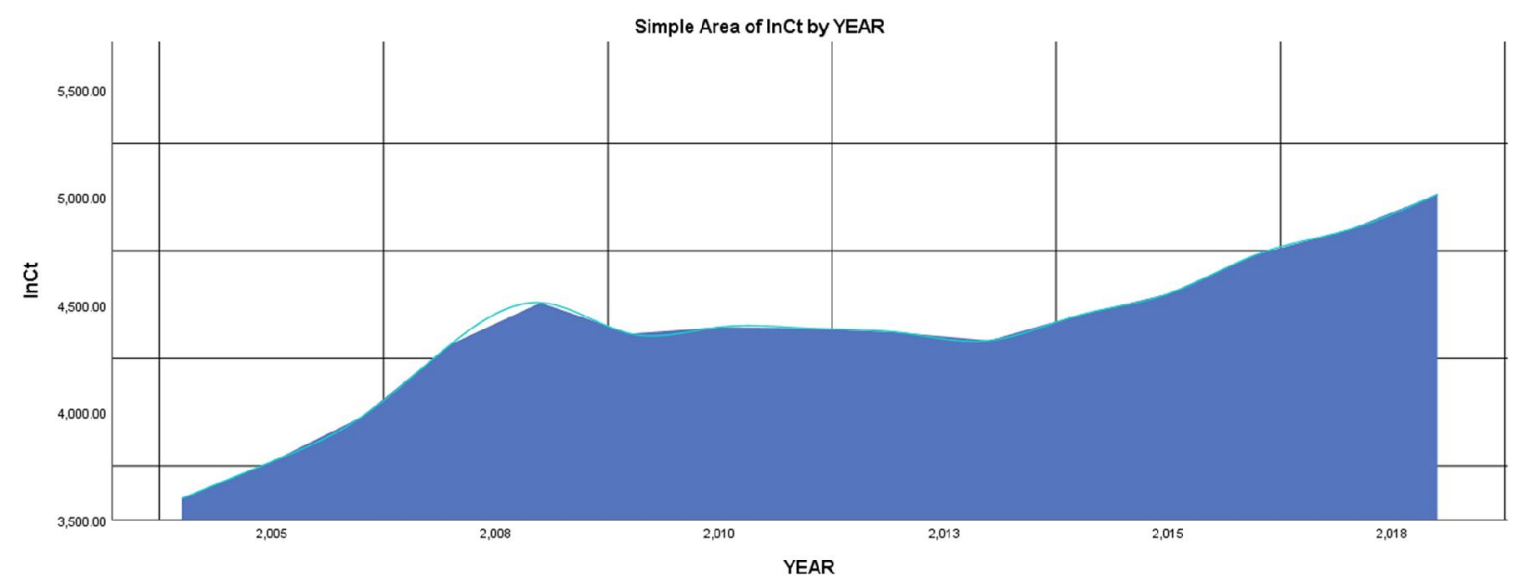

Figure 4. The Ct Performance in the years 2004-2018.

In terms of population growth, all countries have a renaissance trend where it is more pronounced after 2010 onwards. Kosovo is one of the best countries in the sample (there is still a low birth rate) compared to the sample countries which risk in the coming years to burden the state budget with more expenditures for old-age pensions. 


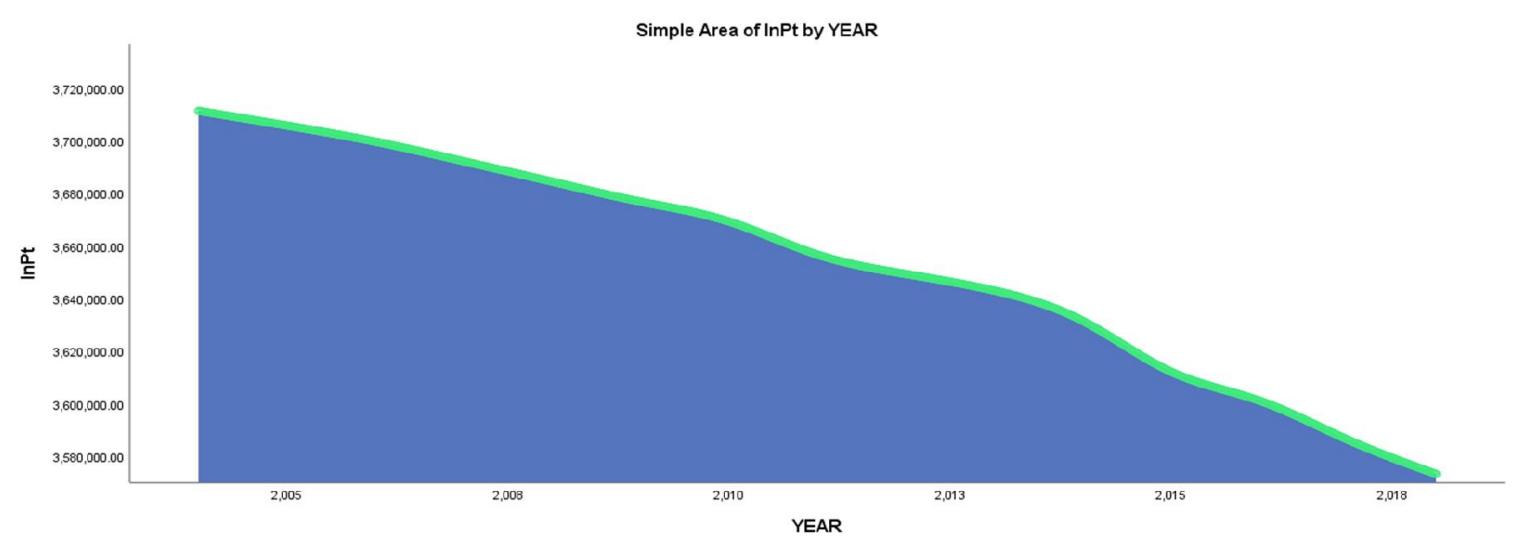

Figure 5. The Pt Performance in the years 2004-2018.

\section{4-2- Normality Test Shapiro- Wilks}

The Shapiro-Wilks test for normality is usually more powerful than two other tests [21]. From the following results, we see that we have parametric data in the Shapiro Wilk case $(\mathrm{p}>.05 \%)$. The following table presents the results from the Shapiro-Wilk normality test: "Sig" has the meaning of p-labeled, the value of the Shapiro-Wilk Test (www.spsstutorials.com/spss-shapiro-wilk-test-for-normality), is greater than 0.05 , the data is normal. If it were below 0.05 , the data would deviate significantly from a normal distribution

Table 7. Normality Test.

\begin{tabular}{cccc}
\hline \multicolumn{4}{c}{ Shapiro - Wilk } \\
\hline Variables & Statistic & Df & Sig. \\
\hline InGS-t & 0.953 & 15 & 0.579 \\
InY_t & 0.963 & 15 & 0.751 \\
InGt & 0.923 & 15 & 0.216 \\
InCt & 0.936 & 15 & 0.332 \\
InPt & 0.946 & 15 & 0.465 \\
\hline
\end{tabular}

So, the judgment: if these variables are normally distributed in the population, there is a 0.579 or $57.9 \%$ probability of finding the abnormality observed in the study data. So, we maintain the invalid hypothesis of population normality because $\mathrm{p}>0.05$. Given this data, we believe that: $\mathrm{P}<0.05$ Reject $\mathrm{H} 0$ of normal distribution in the population.

\section{4-3- Pearson Bivariate Correlation}

Pearson Bivariate Correlation -produces a coefficient of sample correlation, $r$, which measures the strength and direction of linear relationships between pairs of continuous variables te represented by a population correlation coefficient, $\rho$ ("rho"). From the first results, we see that in InGt (Government spendings) we have a total average of all countries of \$34,679.21 with DF (standard deviation) \$ 3,517.89 higher than family consumption $\mathrm{InCt}$ of $\$ 4,374.77$ with a low deviation of $\$ 372.99$.

Table 8. Descriptive analysis.

\begin{tabular}{cccc}
\hline & Mean & Std. Deviation & N \\
\hline InGt & $34,679.21$ & $3,517.89$ & 15 \\
InCt & $4,374.77$ & 372.99 & 15 \\
\hline
\end{tabular}

Pearson Bivariate Correlation results - the use of Pearson Bivariate correlation confirms the first research hypothesis:

- $\mathbf{H}_{1}$ : The complementary effect between private consumption and government spending has a positive effect on the economy.

We can say that $95.2 \%(0.952)$ of the variation in government spending is explained through private consumption. Pearson value, from rho $=.952 * *$ is a highly positive relationship. The value of Sig (2-tail) is 0.000 less than 0.05 (pvalue $<.05 \%$, value $\mathrm{p}=.000<.01 \%$ ) is a statistically significant positive correlation at $1 \%$ of the confidence level.Thus, changes in private consumption are closely related to changes in government spending. 
Table 9. Pearson Bivariate Correlation Analysis.

\begin{tabular}{cccc}
\hline & & InGt & InCt \\
\hline \multirow{4}{*}{ InGt } & Pearson Correlation & 1 & $0.9520^{* *}$ \\
& Sig. (2-tailed) & & 0.000 \\
& Sum of Squares and Cross-products & $173,258,360.38$ & $17,482,405.34$ \\
& Covariance & $12,375,597.17$ & $1,248,743.23$ \\
& $\mathrm{~N}$ & 15 & 15 \\
\hline \multirow{2}{*}{ InCt } & Pearson Correlation & $0.9520^{* *}$ & 1 \\
& Sig. (2-tailed) & 0.000 & $1,947,729.21$ \\
& Cof Squares and Cross-products & $17,482,405.34$ & $139,123.51$ \\
& Covariance & $1,248,743.23$ & 15 \\
\hline
\end{tabular}

$* *$. Correlation is significant at the 0.01 level (2-tailed)

Figure 6, illustrates the relationship between the variables InCt and InGt. The values $\mathrm{x}$ and $\mathrm{y}$ in the example with $\mathrm{r}=$ .952 are as (r) is almost at its maximum value of 1 . In the example with $r=.952$, the linear correlation is therefore quite strong and positive (the slope of the line that fits the data is positive).

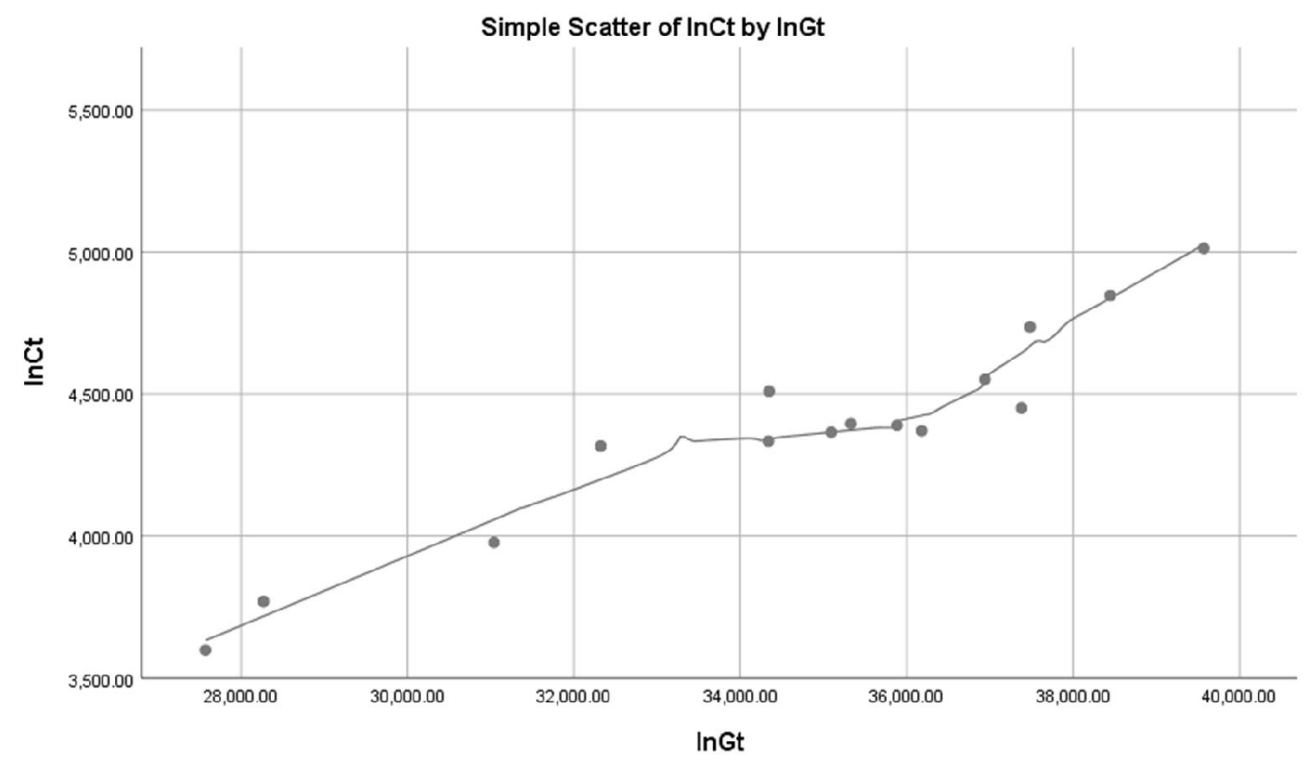

Figure 6. Relationships between InCT and InGt variables.

\section{4-4-Partial Coefficients Correlation}

Partial Coefficients Correlation - To determine which of the independent variables in question play the largest role, the values of the partial correlation coefficients are checked. Through partial correlation, confirms the second research hypothesis:

- $\mathbf{H}_{2}$ : Relationship between Government Expenditures, Private Consumption, per capita income, and population is not positive with all variables.

From the above results, we see that we have a high positive correlation between Gross Savings and Yt in InGt (rho $=0.740, \mathrm{p}$-value $=0.002$ ). Also correlations between the variables InCt with Gross savings (InGS) and Yt is statistically significant and positive (rho $=0.623, \mathrm{p}$-value $=0.017$ and rho $=0.882, \mathrm{p}$-value $=0.000$. Also, the connection is strong and statistically significant correlation between InGt, InCt, and InYt; While, negative and statistically significant correlation was found between Gross savings and total Population- InPt (rho $=-0.370$, $\mathrm{p}$ value $=0.193$ ), also the correlation between InPt and InCt is negative and statistically insignificant (rho $=-0.229$, $\mathrm{p}$ value $=0.431$ ). A positive correlation was also found between $\mathrm{Yt}$, and $\mathrm{InCt}$ with $\mathrm{InGt}(\mathrm{rho}=0.882, \mathrm{p}$ value $=0.000)$. 
Table 10. Partial Correlations.

\begin{tabular}{|c|c|c|c|c|c|c|}
\hline \multicolumn{3}{|c|}{ Control Variables } & \multirow{2}{*}{$\begin{array}{c}\text { GrowsSpct } \\
1.000\end{array}$} & \multirow[t]{2}{*}{$Y_{-} \mathbf{t}$} & \multirow[t]{2}{*}{ InCt } & \multirow[t]{2}{*}{ InPt } \\
\hline \multirow{12}{*}{ InGt } & & Correlation & & & & \\
\hline & $\begin{array}{c}\text { Gross Savings- } \\
\text { InGS-t }\end{array}$ & Significance (2-tailed) & . & & & \\
\hline & & Df & 0 & & & \\
\hline & & Correlation & $0.740 * *$ & 1.000 & & \\
\hline & InY_t & Significance (2-tailed) & 0.002 & . & & \\
\hline & & Df & 12 & 0 & & \\
\hline & & Correlation & $0.623 * *$ & $0.882^{* *}$ & 1.000 & \\
\hline & InCt & Significance (2-tailed) & 0.017 & 0.000 & . & \\
\hline & & Df & 12 & 12 & 0 & \\
\hline & & Correlation & $-0.370 * *$ & $-0.624 * *$ & -0.229 & 1.000 \\
\hline & InPt & Significance (2-tailed) & 0.193 & 0.017 & 0.431 & . \\
\hline & & Df & 12 & 12 & 12 & 0 \\
\hline
\end{tabular}

Note: Correlation is significant at the 0.01 level (2-tailed).

That there is a significant link between private consumption and government spending, gross savings, and per capita income is further strengthened by the figurative representation of the variables.

Correlations

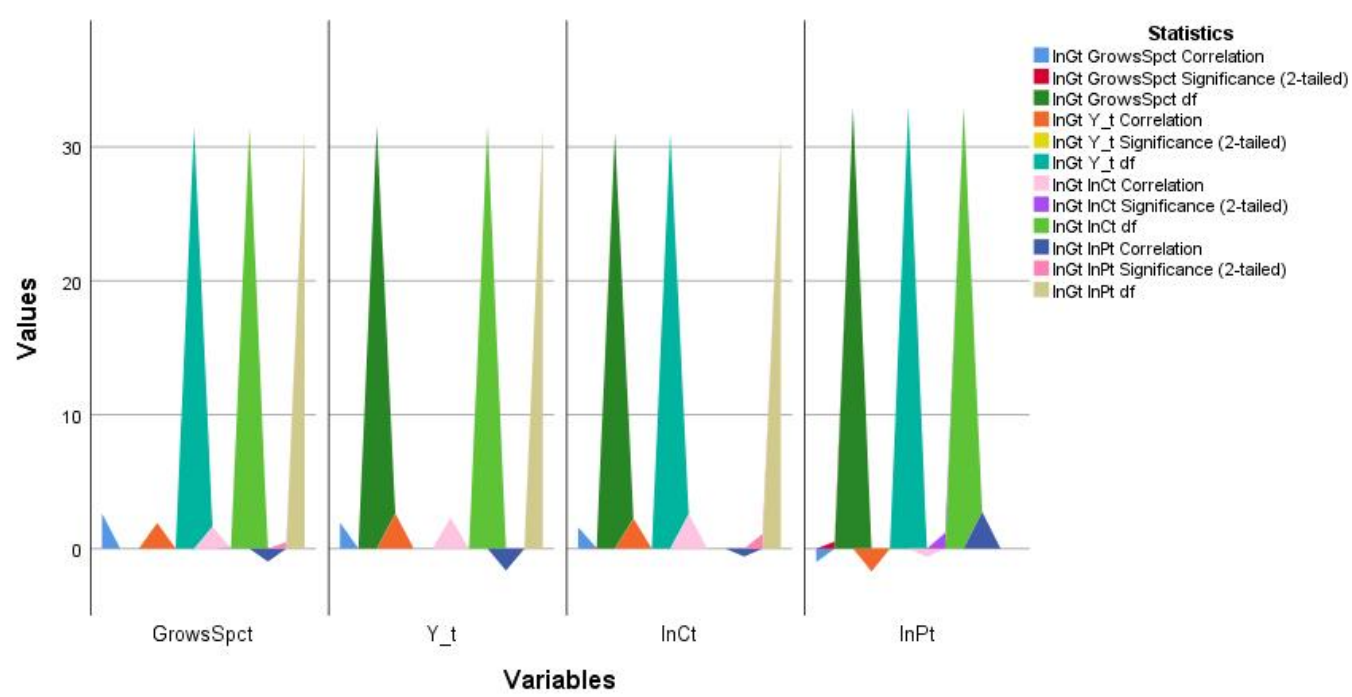

Figure 7. Correlations Relationships between the variants SpCt, Y_t, InCT, InPt.

\section{4-5-The Correlation MATRIC}

The Correlation MATRIC - In the matrix, in a diagonal, the variables are interconnected, the value (r) for these correlations is equal to $(1)$ and the value $(\mathrm{p})$ is $(0.000)$. The above results show a high positive correlation between Gross Saving and Y.t with InGt (rho $=0.740$, p-value $=0.002$ ). Also, the strong and positive link is between Gross Savings (InGS) and Private Consumption (InCt) with Government Spending (Gt) is (rho =0.623, p-value $=0.017$ ). Whereas, no correlation was found between Gross Saving and InPt with $\mathrm{InGt}(\mathrm{rho}=0.370$, $\mathrm{p}$-value $=0.193)$. A positive correlation was also found between InYt and InCt with InGt ( $\mathrm{rho}=0.882$, p-value $=0.000)$. The second hypothesis has been partially validated, Variables Ct, Gt, GS, Yt are positively correlated with each other, while the population (Pt) is negatively correlated with all study variables.

Table 11. Correlation MATRIX.

\begin{tabular}{cccccc}
\hline Variables & Grows-t & Y_t & InGt & InCt & InPt \\
\hline InGS-t & 1.0000 & & & & \\
InY_t & 0.9613 & 1.0000 & & & \\
InGt & 0.9125 & 0.9425 & 1.0000 & & \\
InCt & 0.9466 & 0.9874 & 0.9517 & 1.0000 & \\
InPt & -0.8804 & -0.9333 & -0.8889 & -0.8782 & 1.0000 \\
\hline
\end{tabular}




\section{4-6- The Ordinary Least Squares (OLS)}

Using linear regression (LS) for five countries it has been found that government spending has a positive impact on Private Consumption as long as government spending is productive.

Table 12. Model summary.

\begin{tabular}{ccccc}
\hline Model & R & R Square & Adjusted R Square & Std. Error of the Estimate \\
\hline 1 & $0.952^{\mathrm{a}}$ & 0.906 & 0.898 & 118.86 \\
\hline
\end{tabular}

a Predictor: (Constant), InGt

The value $\mathrm{R}$ represents a simple correlation and is 0.952 , indicating a high degree of correlation. The value of $\mathrm{R} 2$ is .906 and can be explained as $90.6 \%$, which is very large.

Table 13. ANOVA ${ }^{\mathrm{a}}$.

\begin{tabular}{ccccccc}
\hline & Model & Sum of Squares & df & Mean Square & F & Sig. \\
\hline 1 & Regression & 1764038.95 & 1 & 1764038.95 & 124.84 & $0.000^{\mathrm{b}}$ \\
1 & Residual & 183690.26 & 13 & 14130.02 & & \\
1 & Total & 1947729.21 & 14 & & & \\
\hline${ }^{\mathrm{a}}$ Dependent Variables:InCt; ${ }^{\mathrm{b}}$ Predictors:(Constant),InGt & & &
\end{tabular}

The next table is ANOVA, which predicts the dependent variable. This table shows that the regression model predicts the statistically significant dependent variable. Significant value $p=.000$ is less than 0.05 and indicates that the regression model statistically predicts the result.

Table 14. Coefficients.

\begin{tabular}{ccccccc}
\hline \multirow{2}{*}{ Model } & \multicolumn{2}{c}{ Unstandardized Coefficients } & Standardized Coefficients & \multirow{2}{*}{ T } & Sig. \\
\cline { 3 - 5 } & B & Std. Error & Beta & & \\
\hline \multirow{2}{*}{1} & (Constant) & 875.51 & 314.68 & & 2.782 & 0.016 \\
& InGt & 0.101 & 0.009 & 0.952 & 11.17 & 0.000 \\
\hline
\end{tabular}

${ }^{\text {a }}$ Dependent Variable: InCt

The table "Coefficients" provides us with the information needed to predict Private Consumption from Government Expenditures, for the years 2004-2018. It is seen that government spending contributes significantly to the model. We can use the values in column "B" to represent the empirical regression equation:

$C_{\text {it }}=\beta_{0}+\beta_{1} G_{1}=875.51+0.101=875.61$ or $87.6 \%$

As a conclusion in the linear regression equation it is seen that the variable, Government Expenditure has an effect of $87.56 \%$ on the increase of Private Consumption and vice versa. That is, the two main variables of the study complement each other giving positive effects on the economies of the five Western Balkan countries.

\section{5- Discussions}

The coefficients of Bivariate and Partial correlation estimated that Private Consumption and Per capita income are positive and significant in both models. This suggests that higher Private consumption leads to higher Government Spending and vice versa. Moreover, per capita income has a positive effect on Government Spending, which is in line with Wagner's law, the same findings have been confirmed [30, 31].

The research results have confirmed the existence of positive and strong long-term relationships between the variables Private consumption, Government Spending (Gt), Gross Savings (GSt), Per capita income (Yt) as the time delay (In) is used. Whereas, the only variable in which the correlation is strong but negative is the population, which has a negative relationship with all the variables of the study. This suggests that as the population grows, per capita income decreases.

Similar results have also been found in the study [32] in the case of China. The results of the study revealed that government spending have a positive impact on private consumption. Therefore, government spending is a very good instrument to boost the economy and encourage aggregate demand in China during a recession.

However, the result of this study is interesting: 
- First, the response of the economy to the shocks of Government Spending (Gt) and Private consumption (Ct) in the period 2004-2018, has changed depending on the length of periods that have passed the economies of the surveyed countries.

- Second, the impulsive positive response of GDP per capita (GDPpc) to Private Consumption (Ct) and Government Spending (Gt) is expected to be greater.

- Third, Private Consumption (Ct) is seen to have had positive effects on the economy at all times. A strong and positive link between Private Consumption and Government Spending (Gt) is needed in the future as well.

- Fourth, Gross Savings in the analyzed period is seen to have contributed to the growth of investments in the country. Such indicators encourage positive economic growth trends in the coming years.

- Finally, the effect of declining Total Populations (Pt) in countries such as Serbia, Northern Macedonia, and Bosnia and Herzegovina has reduced savings. While countries with a population that has a slight decline and at a young age, Kosovo and Albania, reflect positively on the elasticity of per capita income.

The results in this study found the positive effect of fiscal policy that is associated with positive impulsive responses to some variables that are specifications for the fifteen years. An important suggestion for future researchers is to analyze in their researches, what kind of government services the public spending data provided for each country and what the population consumes more.

\section{6- Conclusions}

After the end of the conflicts, the sample countries choose a growth strategy through trade opening. Since then, the economy has grown somewhere more and somewhere less. Since the 2008 Financial Crisis, governments in sample countries have avoided reducing government intervention in their market and increasing labor market flexibility in line with International Monetary Fund (IMF) recommendations. Since government intervention is small, the economic growth elasticity of government spending is high.

Has been found that public spending in sample countries is productive and growing, affecting the growth of Private Consumption for years. The results of the study confirm that Private Consumption (InCt) and Government Spending (InGt) is in a positive relationship with each other in Kosovo, Albania, Northern Macedonia, Bosnia and Herzegovina, and Serbia in the long run. This is proven through a Bivariate Correlation in the first hypothesis. While it has been proven through partial correlation that the four study variables are in strong positive relationships except for the fifth variable the population which is in negative correlation, the second hypothesis. This is consistent with most of the literature that the higher the population, the income is lower, while this reflects on the smaller amount of income to spend on Private Consumption.

While the consumption decreases, the savings, as well as the possibility of paying public expenses or paying taxes, also decrease. However, the performance and growth of GDP in the sample countries are slow, while government spending is increasing, contributing to the increase in total demand and economic growth. A balanced increase in Government Spending is welcome, giving an effect on Private Consumption.

\section{7- Declarations}

\section{7-1-Data Availability Statement}

The data presented in this study are available on request from the corresponding author.

\section{7-2-Funding}

The author received no financial support for the research, authorship, and/or publication of this article.

\section{7-3-Acknowledgements}

I thank my family for the support they have given me during this research.

\section{7-4-Ethical Approval}

The author gave written consent to use his anonymous data for statistical purposes.

\section{7-5-Conflicts of Interest}

The author declares that there is no conflict of interests regarding the publication of this manuscript. In addition, the ethical issues, including plagiarism, informed consent, misconduct, data fabrication and/or falsification, double publication and/or submission, and redundancies have been completely observed by the author. 


\section{8- References}

[1] Barro, Robert J. "Government Spending in a Simple Model of Endogeneous Growth.” Journal of Political Economy 98, no. 5, Part 2 (October 1990): S103-S125. doi:10.1086/261726.

[2] Fatás, Antonio, and Ilian Mihov. "The effects of fiscal policy on consumption and employment: theory and evidence." Available at SSRN 267281 (2001).

[3] Linnemann, Ludger. “The Effect of Government Spending on Private Consumption: A Puzzle?” Journal of Money, Credit, and Banking 38, no. 7 (2006): 1715-1735. doi:10.1353/mcb.2006.0094.

[4] De Castro, Francisco, and Pablo Hernández de Cos. "The Economic Effects of Fiscal Policy: The Case of Spain.” Journal of Macroeconomics 30, no. 3 (September 2008): 1005-1028. doi:10.1016/j.jmacro.2007.08.009.

[5] Tagkalakis, Athanasios. "The Effects of Fiscal Policy on Consumption in Recessions and Expansions." Journal of Public Economics 92, no. 5-6 (June 2008): 1486-1508. doi:10.1016/j.jpubeco.2007.11.007.

[6] Chen, Yang, and Fushu Luan. "The Effect of Government Expenditure on Private Consumption: Evidence from China." Journal of Global Economics 2, no. 3 (2014): 120. doi:10.4172/2375-4389.1000120.

[7] Albertini, Julien, Stéphane Auray, Hafedh Bouakez, and Aurélien Eyquem. "Taking Off into the Wind: Unemployment Risk and State-Dependent Government Spending Multipliers.” Journal of Monetary Economics 117 (January 2021): 990-1007. doi:10.1016/j.jmoneco.2020.07.007.

[8] Kwan, Yum K. "The Direct Substitution between Government and Private Consumption in East Asia." University of Chicago Press, (2009).

[9] Tervala, Juha. "Productive government spending and private consumption: a pessimistic view." Economics Bulletin 29, no. 1 (2009): 417-426.

[10] Hok, Leanghak. "Non-Linear Effect of Government Spending on Private Consumption in Cambodia: Markov-Switching Autoregressive Model." Journal of Economics and Business 3, no. 1 (2020).

[11] Zouri, Stéphane. "New Evidence on International Risk-Sharing in the Economic Community of West African States (ECOWAS).” International Economics 165 (May 2021): 121-139. doi:10.1016/j.inteco.2020.11.003.

[12] Almosabbeh, Imadeddin Ahmed. "Is the Relationship Between Government Spending and Private Consumption in Egypt Symmetric?" Margin: The Journal of Applied Economic Research 14, no. 3 (July 31, 2020): 285-308. doi: $10.1177 / 0973801020920096$.

[13] Dawood, Taufiq Carnegie, and John Nana Francois. "Substitution between Private and Government Consumption in African Economies.” Economic Modelling 73 (June 2018): 129-139. doi:10.1016/j.econmod.2018.03.012.

[14] Kuncoro, Haryo. "The impact of government consumption on the private expenditures in developing country: the case of Indonesia." Business and Economic Horizons 14, no. 1 (2018): 1-16.

[15] Galton, Francis. "On the Anthropometric Laboratory at the Late International Health Exhibition." The Journal of the Anthropological Institute of Great Britain and Ireland 14 (1885): 205-221. doi:10.2307/2841978.

[16] Legendre, Adrien Marie. Nouvelles méthodes pour la détermination des orbites des comètes: avec un supplément contenant divers perfectionnemens de ces méthodes et leur application aux deux comètes de 1805. Courcier, 1806. Available online: http://documents.univ-toulouse.fr/150BIN/PPN072489561.pdf (accessed on March 2021).

[17] Balakrishna, N., and Chin Diew Lai. "Bivariate Normal Distribution.” Continuous Bivariate Distributions (2009): $477-561$. doi:10.1007/b101765_12.

[18] Pearson, Karl. "VII. Note on Regression and Inheritance in the Case of Two Parents." Proceedings of the Royal Society of London 58, no. 347-352 (December 31, 1895): 240-242. doi:10.1098/rspl.1895.0041.

[19] Gelman, Andrew, and Jennifer Hill. "Data analysis using regression and multilevel/hierarchical models." Cambridge University Press, (2006).

[20] Zuur, Alain F., Elena N. Ieno, and Chris S. Elphick. "A Protocol for Data Exploration to Avoid Common Statistical Problems." Methods in Ecology and Evolution 1, no. 1 (November 13, 2009): 3-14. doi:10.1111/j.2041-210x.2009.00001.x.

[21] Shapiro, S. S., M. B. Wilk, and H. J. Chen. “A Comparative Study of Various Tests for Normality.” Journal of the American Statistical Association 63, no. 324 (December 1968): 1343-1372. doi:10.1080/01621459.1968.10480932.

[22] Rosekrans, P C, C J Meijer, A M van der Wal, C J Cornelisse, and J Lindeman. "Immunoglobulin Containing Cells in Inflammatory Bowel Disease of the Colon: a Morphometric and Immunohistochemical Study." Gut 21, no. 11 (November 1, 1980): 941-947. doi:10.1136/gut.21.11.941. 
[23]Kent State University. "SPSS Tutorials: Pearson Correlation." (2020). Available online: https://libguides.library.kent.edu/spss/pearsoncorr (Accessed on April 2021).

[24] Shapira, Y., D. Y. Kenett, and E. Ben-Jacob. “The Index Cohesive Effect on Stock Market Correlations.” The European Physical Journal B 72, no. 4 (November 10, 2009): 657-669. doi:10.1140/epjb/e2009-00384-y.

[25] Kenett, Dror Y., Michele Tumminello, Asaf Madi, Gitit Gur-Gershgoren, Rosario N. Mantegna, and Eshel Ben-Jacob. "Dominating Clasp of the Financial Sector Revealed by Partial Correlation Analysis of the Stock Market." Edited by Enrico Scalas. PLoS ONE 5, no. 12 (December 20, 2010): e15032. doi:10.1371/journal.pone.0015032.

[26] Baba, Kunihiro, Ritei Shibata, and Masaaki Sibuya. "Partial correlation and conditional correlation as measures of conditional independence." Australian \& New Zealand Journal of Statistics 46, no. 4 (December 2004): 657-664. doi:10.1111/j.1467842x.2004.00360.x.

[27] World Bank. "Western Balkans Regular Economic Report No. 18, Fall 2020: An Uncertain Recovery.” (2020). Available online: https://openknowledge.worldbank.org/bitstream/handle/10986/34644/153774.pdf (Accessed on March 2021).

[28] Schiffbauer, Marc Tobias, and World Bank. "Western Balkans Regular Economic Report, No. 17, Spring 2020: The Economic and Social Impact of COVID-19." (2020). Available online: https://openknowledge.worldbank.org/handle/10986/33670 (Accessed on March 2021).

[29] Dustatis. Statistiches Bundemsant (2020). COVID-19 leads to a decline in private consumption expenditure in 2020. Available online: https://www.destatis.de/Europa/EN/Topic/Economy-Finance/PrivateConsumption.html (Accessed on March 2021).

[30] Keho, Yaya. "What Drives Energy Consumption in Developing Countries? The Experience of Selected African Countries." Energy Policy 91 (April 2016): 233-246. doi:10.1016/j.enpol.2016.01.010.

[31] Keho, Yaya. "Dynamic Relationship between Government Spending and Private Consumption: Evidence from Cote d'Ivoire." International Journal of Economics and Financial Issues 9, no. 1 (January 1, 2019). doi:10.32479/ijefi.7433.

[32] Khan, Khalid, F. E. I. Chen, and Nadeem Ashraf. "Impact of government spending on private consumption using ARDL approach." Asian Economic and Financial Review 5, no. 2 (2015): 239-248. 